DOI: $10.2478 / \mathrm{v} 10014-010-0011-3$

Agrovoc descriptors: mamestra brassicae,lacanobia oleracea,vegetables, pest control, pests of plants, plant protection, natural enemies,monitoring,seasonal variation

Agris category code: $\mathrm{H} 10$

\title{
Cabbage moth (Mamestra brassicae [L.]) and bright-line brown-eyes moth (Mamestra oleracea [L.]) - presentation of the species, their monitoring and control measures
}

\author{
Marko DEVETAK ${ }^{1}$, Matej VIDRIH ${ }^{2}$, Stanislav TRDAN ${ }^{3}$
}

Received January 25, 2010; accepted May 28, 2010.

Delo je prispelo 25. januarja 2010; sprejeto 28. maja 2010.

\begin{abstract}
The paper describes polyphagous pests, the cabbage moth (Mamestra brassicae) and bright-line brown-eyes moth (Mamestra oleracea), which were not systematically investigated up to now in Slovenia. The cabbage moth, which is more abundant, preferably attacks Brassica plants, and its caterpillars are especially harmful in the cabbage. The paper deals with the morphology, distribution and methods of monitoring the pest populations and discuss on their control. The protection of vegetables from both pests is primarily based on the use of chemical insecticides. However, the use of natural enemies and various agro-technical measures can also be very important in diminishing the populations of the pests. With interlacing of all of these approaches, healthy and quality food can be produced even in the growing seasons with high attack of the pests mentioned.
\end{abstract}

Key words: cabbage moth, Mamestra brassicae, bright-line brown-eyes moth, Mamestra oleracea, presentation, distribution, damage, monitoring, control

\section{IZVLEČEK}

\section{KAPUSOVA SOVKA (Mamestra brassicae [L.]) IN ZELENJADNA SOVKA (Mamestra oleracea [L.]) - PREDSTAVITEV VRST IN UKREPOV ZA NJIHOVO SPREMLJANJE IN ZATIRANJE}

V prispevku sta predstavljena polifagna škodljivca, kapusova sovka (Mamestra brassicae) in zelenjadna sovka (Mamestra oleracea), ki v Sloveniji doslej nista bila načrtneje preučevana. Kapusova sovka, ki se pri nas pojavlja bolj številčno, najraje napada kapusnice, njene gosenice pa se najraje hranijo na zelju. $\mathrm{V}$ prispevku predstavljamo morfologijo, razširjenost, način spremljanja sezonske dinamike vrst ter njuno zatiranje. Varstvo vrtnin pred kapusovo sovko in zelenjadno sovko še vedno temelji zlasti na uporabi kemičnih insekticidov, čeprav je številčnost populacij omenjenih škodljivcev mogoče zmanjšati tudi z naravnimi sovražniki in ustreznimi agrotehničnimi ukrepi. S prepletanjem omenjenih ukrepov je namreč mogoče tudi ob močnem napadu pridelati zdrav in kakovosten živež.

Ključne besede: kapusova sovka, Mamestra brassicae, zelenjadna sovka, Mamestra oleracea, predstavitev, razširjenost, škodljivost, spremljanje, zatiranje

\section{INTRODUCTION}

Cabbage moth (Mamestra brassicae [L.]) and brightline brown-eyes moth (Mamestra/Lacanobia oleracea [L.]) are classified into family Noctuidae (owlet moths and underwings) and order Lepidoptera (butterflies, moths, and skippers). Both pests are polyphagous, their larvae feed with aboveground parts of plants in night and morning hours. During the day caterpillars are hiden under the leaves and in the aboveground plant parts near to the soil surface. Damage is visible on leaves and flowers of vegetables and occasionally also

\footnotetext{
${ }^{1}$ B. SC., Damber 3, SI-5000 Nova Gorica

${ }^{2}$ Assist. Prof., Ph. D., Biotechnical Faculty, Dept. of Agronomy, Jamnikarjeva 101, SI-1111 Ljubljana

${ }^{3}$ Assoc. Prof., Ph. D., Biotechnical Faculty, Dept. of Agronomy, Jamnikarjeva 101, SI-1111 Ljubljana, email: stanislav.trdan@bf.uni-lj.si
} 
on fruits of horticultural plants. Cabbage moth is treated as one of the most important Brassica pest, while bright-line brown-eyes moth rather attacks tomato and lettuce. From time to time caterpillars from both species cause larger damage also on tobacco plants. Pests prefer specially grounds where weeds are grown or no herbicides are used (Sannino, 2005). In last period when rainy and not too hot summers prevailed, we observe also in Slovenia larger appearance of caterpillars from genus Mamestra. With the purpose of studying their bionomics and representative ratio ob both species we placed pheromone traps on two locations in the period from 2008 to 2009. The results of male catches will be used in preparing their control strategy and in present paper we present both pest species and measures for their monitoring and control if eventual outbreak in the near by future appears.

\section{CABBAGE MOTH (Mamestra brassicae [L.])}

\subsection{Distribution and damage}

Cabbage moth is distributed in Europe and in greater part of Asia (Pollini, 2006). It feeds mainly on Brassica plants, leaves of sugar beet, tobacco, sunflower and cereals. Beside these plants it makes damage to spinach, tomato, potato, mangold, lettuce and pepper. Metspalu et al. (2004) report that larvae of above mentioned pest most likely feed with leaves of white cabbage (Brassica oleracea convar. capitata var. alba) (Figure 1) and red cabbage (Brassica oleracea var. capitata var. rubra). As regards the susceptibility borecole (Brassica oleracea convar. acephala var. sabellica) follows the cabbage and the Brassica species, which attracts caterpillars less, is oilseed rape (Brassica napus L. subsp. napus).

Feeding of insects depends on the period between separate meals and the quantity of consumed energy in this time interval (Shimizu in Yagi, 1983). More than one thousand substances are known, which are emitted by the plants into the environment with the aim to attrack other organisms (Ulland, 2007). Volatile components affect directly on organisms in a way that they lure them to oviposit or they have an indirect role as an attractant for natural enemies of the pests.

Sannino and Espinoza (1998) report about the noxiousness of cabbage moth on peach fruits, while Pollini (2006) report about the same on pears. Caterpillars reach the branches which are closer to the ground and cause round bores in fruits (Corvi and Nardi, 1998). In a laboratory experiments, conducted by Sannino in Espinoza (1998), moths fed also on meadow plants such as ribwort plantain (Plantago lanceolata L.) and common sowthistle (Sonchus oleraceus L.). Caterpillars feed during the night time and are most noxious in autumn when they eat mainly leaves of vegetables.

Beside the mechanical damages, caterpillars lessen the quality of crops also through their excrements on flowers and leaves (Pelosini, 1999). Their indirect influence can be observed through the transmission of pathogenic fungi and bacteria into attacked plants (Corvi in Nardi, 1998).

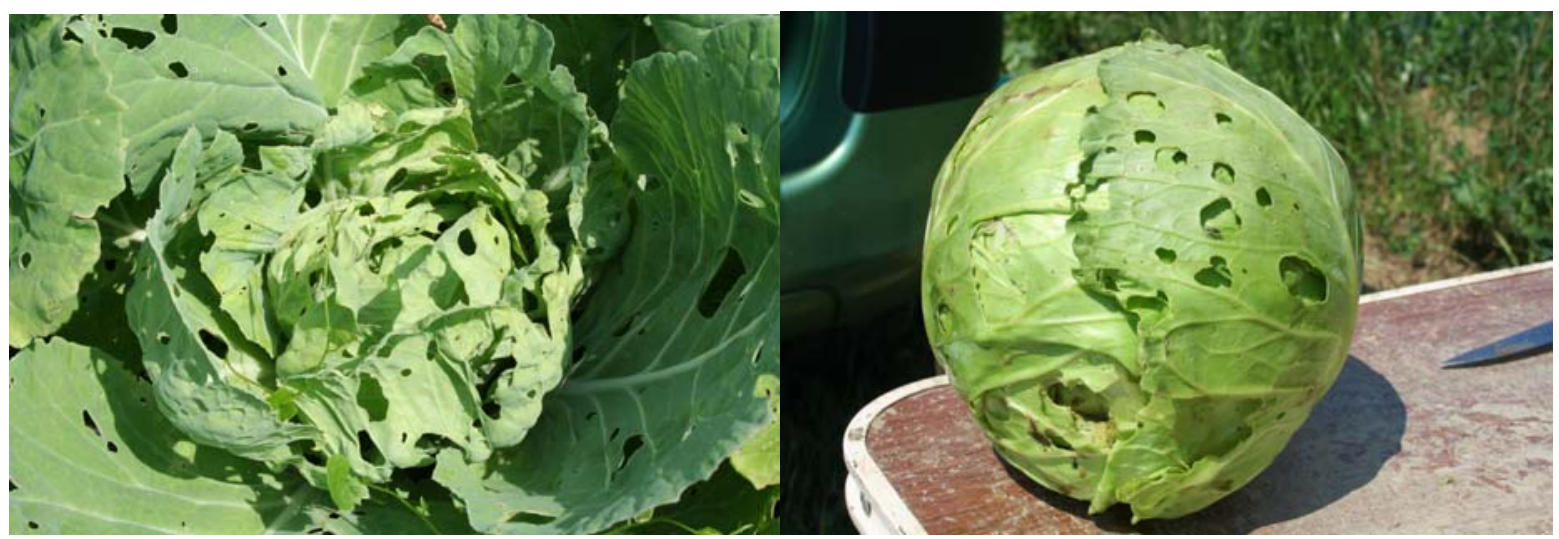

Figure 1: Damage caused by Mamestra caterpillars on the exterior leaves of cabbage plant (left) and cabbage head (right) (photos: S. Trdan)

\subsection{Morphology}

The forewings are brown and mottled with a prominent whiteedged stigma and a broken white subterminal line. The hindwings are grey, darker towards the termen. The species varies considerably in size, with a wingspan of $34-50 \mathrm{~mm}$. The prominent spur on the tibia of the foreleg is a diagnostic feature (Pollini, 2006). 


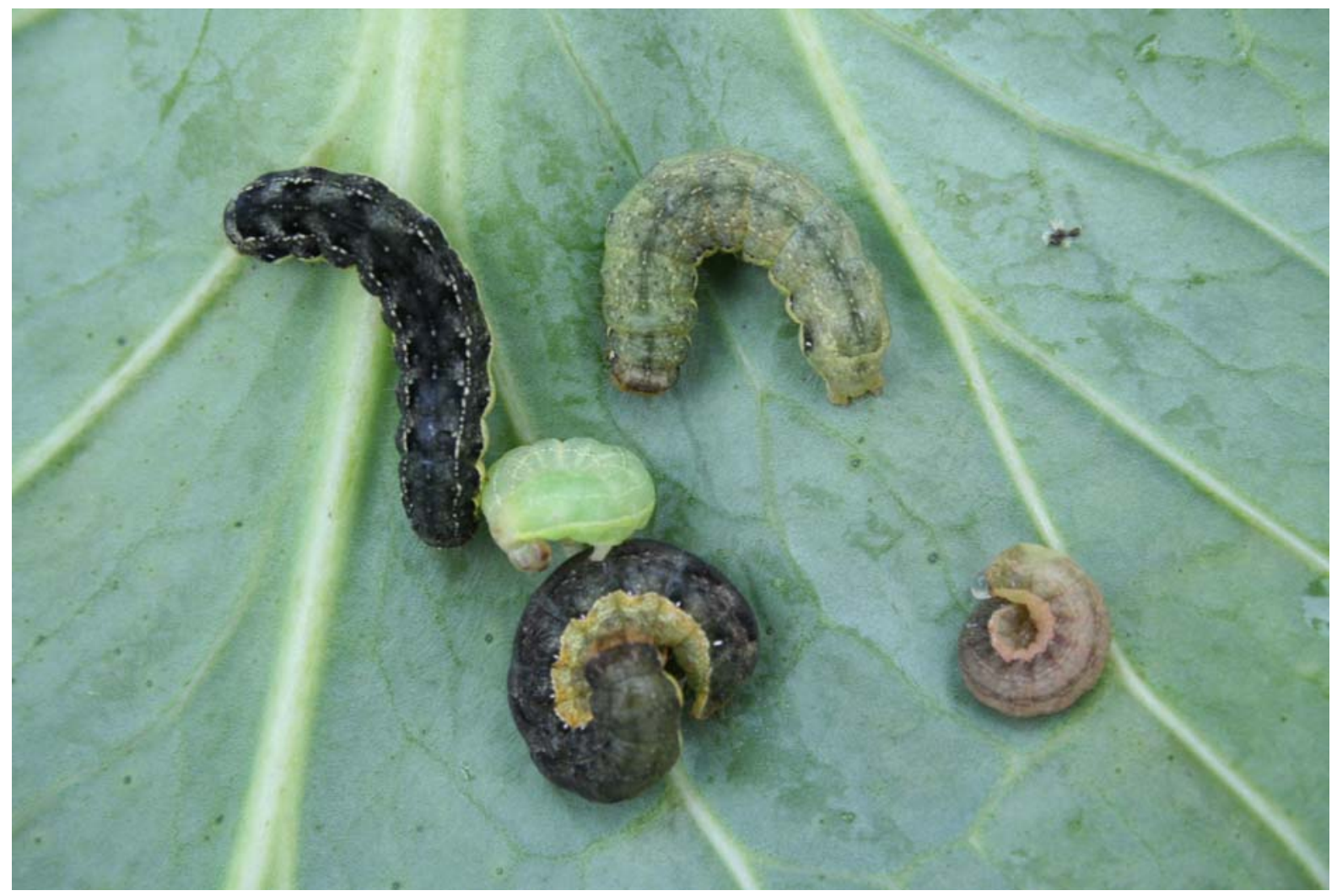

Figure 2: Different caterpillar instars of the cabbage moth (Mamestra brassicae [L.]) (photo: S. Trdan)

Eggs are slightly oblong and ridged lengthwise. A redbrown marking is in the middle of egg. An egg has 1.2 $\mathrm{mm}$ in diameter. First instar caterpillar is yellow-green and its three pairs of legs on thorax, a pair of appendages (anal prolegs) at the posterior end, and one to four pairs of abdominal prolegs in between are black. The caterpillars of first five instars have copper like head and abdomen is lightly green with white stripe which goes above stigmata. The sixth instar caterpillar is brown on dorsal side and yellow on ventral one and is $40 \mathrm{~mm}$ in length. Head stays copper like coloured (Figure 2). Pupa is $20 \mathrm{~mm}$ long and red-brown (Pollini, 2006).

\subsection{Bionomics}

First generation adults appear in Italy from the end of April till the beginning of June. Butterflies fly at night and look for cover between the plants during the day. After the copulation female lays up to 2500 eggs on lower surface of leaves in clusters from 25 to 350 eggs. Incubation period depends from the environmental factors. At $25{ }^{\circ} \mathrm{C}$ the incubation period is 5 days and at lower temperatures it lasts from 10 to 12 days. Larvae have up to six stages. First generation of pest develops in 20 to 30 days at temperature from 20 to $25^{\circ} \mathrm{C}$ and the second one develops in autumn. It lasts from 40 to 60 days at 12 to $15{ }^{\circ} \mathrm{C}$. Adult caterpillars pupate in the ground, at the depth from 2 to $4 \mathrm{~cm}$. Butterflies come in sight again in July and fly till the first half of October. Species is most abundant between middle of September and middle of October. Butterflies lay eggs from which larvae of the second generation develops and after that overwinter as pupae (Pollini, 2006).

Cabbage moth has up to two or even three generations annually in Middle and South Europe, meanwhile Johansen (1996) from Norway reports only about one generation. It is characteristic for pupae of cabbage moth that they have diapause, which is a consequence of environmental temperature, photoperiod and food quality. Pupae diapause of first generation lasts till 80 days and in winter time for six months (Sannino in Espinosa, 1998). 


\section{BRIGHT-LINE BROWN-EYES MOTH (Mamestra/Lacanobia oleracea [L.])}

\subsection{Distribution and damage}

Bright-line brown-eyes moth is distributed in the area of EuroAsia and North Africa. It's a polyphagous insect and most likely feeds with vegetables such as tomato, lettuce, cabbage, root and petiole celery and mangold. It feeds also on soybean, tobacco, sugar beet and even with trees like willow and elm tree. Pest attacks also fruit trees, mostly apple tree and peach tree (Pollini, 2006).

In the beginning caterpillars cause minor damages on lower surface of leaves and in later stages, when their feeding is more formed they can easily eat greedily the whole leaf mass. Damage made by caterpillars can be observed also on apples and peaches, particularly in extensive plantation where less plant protection products is used (Pollini, 2006).

\subsection{Morphology}

The forewings are brown and mottled with a prominent white-edged stigma and a broken white subterminal line. When forewings are stretched they amount from 30 to $50 \mathrm{~mm}$. On wings there are two yellow spots and two spots of brown colour. Hind wings are grey. Thorax is red-brown and abdomen is lightly brown. Hind tibia is lacking a hooked terminal spur (INRA, 2008).

Eggs of bright-line brown-eyes moth are bright green, hemispherical and flattened on the substratum. They are $0.7 \mathrm{~mm}$ in length (Pollini, 2006). Caterpillars are dark green with a light brown head and dark and yellowish white light stripes along the body. These stripes are less visible when larvae are close to pupation. They measure 35 to $40 \mathrm{~mm}$ in length when fully grown (INRA, 2008). They go through five instars to pupate. Young caterpillars are often found in groups feeding near the egg mass. Older caterpillars disperse moving from plant to plant. Caterpillars actively feed for 10 to 18 days, descending into the soil to pupate. They have 16 legs and false legs together (Vacchi in Cioni, 2006). The pupa is yellowish green when formed, turns dark brown later and measures from 16 to $19 \mathrm{~mm}$ in length (Pollini, 2006). Pupation takes place in a loose silken cocoon 2 to $6 \mathrm{~cm}$ below soil surface. Complete developmental cycle lasts for 30 days (Vacchi in Cioni, 2006).

\subsection{Bionomics}

In the second half of April butterflies appear and still fly in May and June and stay active during the night time. Females of bright-line brown-eyes moth lay eggs similar as females of cabbage moth on the underside surface of the leaves in clusters of 200 to 800 eggs. Embrional development brings to an end after five to ten days. Young caterpillars leave some days together and then separate. After the end of development caterpillars pupate into the ground, at the depth of 10 $\mathrm{cm}$. Adults of second generation fly from the end of July to August. Often they fly also in September and in the beginning of October. Caterpillars of second generation mature in second half of October and overwinter in diapause (Vacchi in Cioni, 2006).

\section{MONITORING MOTHS FROM GENUS Mamestra}

Moths (Noctuidae) control is based upon the application of chemical insecticides. To gain more reasonable and effective usage, plants should be treated in time when caterpillars are younger and feed only on outer leaves and at least 10 to $15 \%$ of leaf area is damage. Convenient time for treating the attacked plants is evening or morning when caterpillars are more active (Vacchi and Cioni, 2006).

To achieve optimal efficiency of insecticides the caterpillars of cabbage moth must be smaller than 12 mm (Johansen, 1996). Older and larger caterpillars hide between plant leaves and are better protected against insecticides. Suchlike example is iceberg salad which offers due to the rosette compactness a good hideout to bright-line brown-eyes moth (Gengotti, 2008).
Because the development of cabbage moth and brightline brown-eyes moth larvae depends mostly from the environmental temperature it is very uncertain to predict accurate time of treatment on a predefined area. That is why constant monitoring of butterfly seasonal dynamic is needed. Monitoring of adults can be done in different ways. Among more known and prosperous detection methods is usage of pheromone traps. With this method we can allure males and prevent copulation. The trap also helps to determine the most proper time to apply insecticides. Pop et al. (1999) refer that pheromone traps, which are used to control and monitor butterflies, can be improved with a supplement of ethers what makes such traps much cheaper. While pheromone traps help us to monitor the population dynamic of the pest, the expected damage assessment must be done through determination of oviposition and pertinent egg development (Corvi and Nardi, 1998). 
Insect light traps with mercury bulbs with wavelength till $400 \mathrm{~nm}$ can be used to monitor moths. But their disadvantage is unselectivity that is why such traps are used in abundance research of different harmful, beneficial and indifferent species in the environment (Dodok, 2003). Following the results of the experiment in which many butterflies was determined with pheromone traps in the period of three years, Johansen (1996) developed a mathematical model for predicting of cabbage moth with consideration of daily temperature in Norway.

Butterfly catch of cabbage and bright-line brown-eyes moths is likely low with regard to the extent of the damage, which can be caused by caterpillars. Campagna (2005) quoted that this could be due to the polyphagous characteristic of these pests.

\section{CONTROL OF CATERPILLARS FROM GENUS Mamestra}

\subsection{Chemical control}

In controlling leaf moths still mostly are used organic phosphorus esters. In this group we classify active compounds such as chlorine pirifos-methil, phenitrotion and acephate (Pelosini, 1999). Sufficient efficacy in this relation we can attain also with pyrethroids (cypermethrin, deltamethrin, lambda-cyhalothrin, betacyfluthrin and tefluthrin). In Slovenia registered products for controlling cabbage moth are from a group of pyrethroids, a product on the basis of pyrethrin, a product which corresponds to oxadiazine and one from the group of insect development inhibitors (IRI). Pyrethroids which are registered in Slovenia are Fastac $10 \%$ SC (alfa-cypermethrin) and Karate Zeon 5 CS (lambda-cyhalothrin). Latter is the only registered insecticides for controlling bright-line brown-eyes moth.

Two products are also used when controlling cabbage moth, namely pyrethrin (Spruzit powder) and indoxacarb (Steward). Active ingredient indoxacarb refers to the group of oxadiazines which is also advanced one. Insecticides from the oxadiazines group block Na-channels in nerve fibers. Target insects stop feeding, stay paralyzed and die soon. Product Steward is suitable for integrated production.

Chitinase inhibitors display minor danger for human being and are suitable specially for controling eggs and young larvae (Corvi in Nardi, 1998). Among inhibitors of insect development we assign active ingredients such as teflubenzuron, esaflumuron and lufenuron (Pelosini, 1999). The last one is registered in Slovenia and represents an active ingredient of product Match 050 EC.

If there are caterpillars of various developmental stages on the ground, Corvi and Nardi (1998) recommend the application of pyretroids or carbamates. Both groups of insecticides belong to neurotoxins and act as a contact or stomach insecticides. In case if we want controlling also other pest species on plants, the authors recommend the usage of organic phosphorus esters which acts through the respiratory system.
In case of cabbage moth control on cauliflower (Brassica oleracea var. botrytis) in autumn, Corvi and Nardi (1998) advise double treatment with synthetic insecticides (pyretroids, carbamates, organic phosphorus esters and growth regulators) and at least spraying with microbiological products on the basis of Bacillus thuringiensis var. kurstaki.

\subsection{Crop protection with natural products}

Beside the insecticides with chemical components, in integrated and biological production the products of natural origin are more and more used (Gengotti in Censi, 2004). Along effective natural products recon bacterium Baccilus thuringiensis var. kurstaki, which replaces in some places considerable amount of chemical products. Azadirachtin, rotenone and natural pyrethrin showed in some experiments good results when controlling cabbage moth and bright-line browneyes moth as well.

Azadirachtin is a natural insecticide present in the seeds of tropical plant Azadirachta indica A. Juss. Its characteristic is low toxicity to mammals. The product acts systemically while it is absorbed through the roots and leaves. From there it is transported to other parts of the plant. Azadirachtin has a wide spectrum of control, however it does not cause instant death of an insect but alters the life-processing behavior in such a manner that the insect can no longer feed, breed or undergo metamorphosis. Products from azadirachtin have short withholding period and are intended for preventive treatments (Gengotti in Censi, 2004).

Bacillus thuringiensis is an aerobic bacterium which produces toxin. This toxin activates in target organism after the consumption. Caterpillars which eat up treated parts of the plants immediately stops feeding and dies in few days. Bacterial subspecies kurstaki and aizawai are specially appropriate in controlling larvae from order Lepidoptera, while subspecies tenebrionis and israelensis have suitable insecticidal control of organisms from orders Coleoptera and Diptera. Benefit 
of products with active ingredient Bacillus thuringiensis var. kurstaki when compared to other products which are also used against cabbage moth and bright-line brown-eyes moth is the fact that product is nontoxic for vertebrates and does not harm beneficial insects. Due to the leaching and photolability spraying with abovementioned insecticidal product is needed to be repeated frequent.

Pyrethrins are compounds which are gained with maceration of flowers from plant Chrysanthemum cinerariaefolium Vis. and which are not toxic to mammals. They have a broad control spectrum but the problem causes their non selective control and weak persistence on plants which leads to reappeared presence of pest on plants in a short time (Gengotti in Censi, 2004). To prolong the persistence of products natural or synthetic compounds like for example piperonil butoxide are added (PBO).

Rotenon is obtained from tropical legume Derris elliptica (Wallich) Benth. Insecticides which contain aforementioned compound are very toxic for mammals and beneficial insects. Its characteristic is fast control to pest organisms and has longer withholding period as it comes up to ten days (Gengotti in Censi, 2004).

\subsection{Biological control}

Natural enemies of cabbage moth and bright-line brown-eyes moth are bacteria, birds, lizards and insects. The latter are the most important, particularly members of Diptera and Hymenoptera families. It is well known that natural enemies attack specially individuals of last generation, namely at the end of summer and in autumn (Vacchi, 2006).

Tramblay (1993) acknowledges that cabbage moth could have more than 50 different natural enemies. One of the most efficient is parasitoid Trichogramma evanescens Westwood which feeds with moth eggs and can reduce the pest population also up to $80 \%$. Similar efficiency can be observed also with Trichogramma dendrolimi Matsumura which can destroy 60 to $80 \%$ of cabbage moth eggs. Beside the effective egg control this hymenopteran species is appropriate also for its simple host breeding. Takada et al. (2000) tried to breed Trichogramma dendrolimi exclusively on Mediterranean flour moth (Ephestia kuehniella Zeller) as a host species. After the twelve generation of parasitoid which bred on above mentioned host, the females of parasitoid Trichogramma dendrolimi still rather choose specimens of Mamestra brassicae. They also report that eggs found in cabbage moth cadavers were bigger from those found in Mediterranean flour moth cadavers and that female also laid two times more eggs in cabbage moth (Takada et al., 2000).
Beside aforementioned organisms, also some important parasitoids of moth caterpillars exist, such as Meteorus gyrator (Thunberg), Exorista larvarum (L.), Exorista fasciata (Fallén), Nemoraea pellucida (Meigen) and Compsilura concinnata (Meigen). Very important parasitoids Amblyteles armatorius (Förster) and Pimpla instigator F. are from family Ichneumonidae; their larvae feed with caterpillars of cabbage moth and bright-line brown-eyes moth (Sannino in Espinosa, 1998).

Sannino (1998) references on effective biological control of Protapanteles praecipuus (Papp) from family Braconidae in a laboratory experiment. This parasitoid lays more than ten eggs into the caterpillar which afterwards develop into the larvae. Moth caterpillar dies in few days and parasitoid larvae pupate outside the prey's body.

Meteorus gyrator appears in the area of North Europe, Great Britain, Asia and North Africa (Smethurst et al., 2004). This endoparasitoid has a wide spectrum of hosts, among which the most frequent from order Lepidoptera are owlet moths (Noctuidae), geometrid moths (Geometridae) and Lymantriidae (tussock moths). Only one egg is laid by the wasp in victim's body. Despite the general opinion that Meteorus gyrator is a superior adapted parasitoid (superparasitoid), Smethurst et al. (2004) ascertained that sometime in victim's body from which larva already came out, later laid egg or larva of wasp can still be found. Introduced phenomenon at this host indicates to incapability of separating between parasited and unparasited hosts. Among moths the wasp parasites mostly caterpillars of bright-line brown-eyes moth. A slow growth of wasp infected organisms compared to normal one is characteristic trait and after the end of parasitizing the host is exploited. Differences exist also in time of parasitoid development, which depends from the development of host organism. It was discovered that this wasp has the longest development in caterpillars of cabbage moth (Smethurst in sod., 2004).

Exorista larvarum appears infrequently and oviposites eggs on the surface of victim's body. Caterpillars which contain eggs are identified after the dark spot, which lies in the place where endoparasite entered the victim's body (Sannino in Espinosa, 1998).

\subsection{Interseeding and intercropping}

With the aim to restrain the use of chemical products for plant protection and to lessen the number of pest organisms, the application of intercrops and mixed crops of two or more plants is used on farm holdings. Diverse ecosystem enable the presence of higher 
number of natural enemies which helps to control pest organisms.

Theunissen et al. (1995) reported about the findings in which white clover (Trifolium repens L.) as an intercrop can reduce the number of different pests on cole crops. Pests which are mentioned are cabbage aphid (Brevicoryne brassicae L.), flea beetles (Phyllotreta spp.), onion thrips (Thrips tabbaci Lindeman) and cabbage moth.

According to Wiech and Kalmuka (2004) white clover acts as the best intercrop against moth larvae. Larvae which move between the white clover plants during the search for the food are exposed to natural enemies such as beetles from the family Carabidae.

\section{CONCLUSIONS}

Representative members of owlet moths (Noctuidae), specially cabbage moth and bright-line brown-eyes moth, can cause serious troubles to cole crops and vegetable growers. To restrict their attacks beside the use of chemical insecticides also natural products which are environmentally friendly in larger extent are used. As important measure to take into consideration in vegetable production beside new insecticides is also soil cultivation. Among latter worth to mention are deep autumn cultivation with the aim to destroy overwintered pupae, use of interseeding, intercropping and cover crops.

Next to above mentioned measures, more significance is given to natural enemies of pest organisms. They harm or totally destroy eggs and moth caterpillars. Their application is recommended particularly for growing vegetables in greenhouses (hydroponics growing) where their efficacy is expected to be much higher. Some natural enemies of moths as parasitoid Trichogramma evanescens, represent remarkable potential in plant protection in the future and at the same time enable lower environmental burden. This is why more attention should be given in searching species from genus Trichogramma on the territory of Slovenia as momentarily we do not have any information on their abundance. If their domestic status will be confirmed, they could be introduced into food production systems.

\section{ACKNOWLEDGEMENT}

This work was carried out within Horticulture No P40013-0481, a program funded by the Slovenian Research Agency, and within the V4-0524, project funded by the Slovenian Research Agency and Ministry of Agriculture, Food, and Forestry of the Republic of Slovenia. Part of the research was funded within
Professional Tasks from the Field of Plant Protection, a program funded by the Ministry of Agriculture, Forestry, and Food of Phytosanitary Administration of the Republic of Slovenia.

\section{REFERENCES}

Campagna G. 2005. Dalla semina in prose della bietola buoni risultati. L'Inf. Agrar., 46: 41-45.

Corvi F., Nardi S. 1998. Combattere la nottua del cavolfiore. Terra e vita 47: 76-78.

Dodok I. 2003. Noctuidae (Lepidoptera) of the Užice Region (Western Serbia). Acta Entomol. Serb., 8: 1-13.

Gengotti S. Gli insetticidi piu efficaci contro le nottue della lattuga. L'Inf. Agrar., 18: 36-38.

Gengotti S., Censi D. 2004. Il controllo delle nottue fogliari su lattuga in coltivazione biologica. L'Inf. Agrar., 23: 4952 .

INRA $2008 \quad$ http://www.inra.fr/hyppz/RAVAGEUR/ 6mambra.htm (20. julij 2008)

Johansen N. S. 1996. Prediction of Field Occurence of Cabbage moth, Mamestra brassicae (Lepidoptera:
Noctuidae): Pheromone and degree-day model. Nor. J. Agric. Sci., 10: 541-553.

Metspalu L., Jogar K., Hiiesaar K., Grishakova M., 2004. Food Plant Preference of the Cabbage Moth, Mamestra brassicae (L.). Latv. J. Agron. 7: 15-19.

Pelosini P. 1998. La lotta integrata. Terra e vita 24: 76-78.

Pollini A. 2006. Manuale di entomologia applicata. $1^{\text {a }}$ edizione. Milano, Edagricole: 1462 str.

Pop L., Arn H., Oprean L., Rauscher S., Chis V., Szabo A. 1999. Pheromone analogues with ether structure: a preliminary report. IOBC wprs Bull. 22, 9: 37-43

Sannino L. 2005. Danni da insetti al tabaco. Inf. Fitopatol., 2: 7-10. 
Sannino L., Espinosa B. 1998. Ciclo biologico di Mamestra brassicae e danni alle colture ortive in Campania. Inf. Fitopatol., 5: 59-67.

Shimizu T., Yagi S. 1983. Feeding Manner of Lepidopterous Larvae: The Cabbage Armyworm Mamestra brassicae L. (Lepidoptera: Noctuidae) and the Common Armyworm, Leucania separata Walker (Lepidoptera: Noctuidae). Jpn J. Appl. Entomol. Zool, 18: 278-280.

Smethurst F., Bell H. A., June Matthews H., Edwards J. P. 2004. The comparative biology of the solitary endoparasitoid Meteorus gyrator (Hymenoptera: Braconidae) on five noctuid pest species. Eur. J. Entomol., 101: 75-81.

Takada Y., Kawamura S., Tanaka T. 2001. Host preference of Trichogramma dendrolimi (Hymenoptera: Trichogrammatidae) on its native host, Mamestra brassicae (Lepidoptera: Noctuidae) after 12 continuous generations on a factitious host. Appl. Entomol. Zool. 36: $213-218$.
Theunissen J., Booijc J. H., Lotz L. A. P. 1995. Effects of Intercropping White Cabbage with Clovers on Pest Infestation and Yield. Entomol. Exp. Appl. 74: 7-16.

Tremblay E. 1993. Entomologia applicata. Liguori 2: 437str.

Ulland S., 2007. Functional Characterization of Olfactory Receptor Neurons in the Cabbage Moth Mamestra brassicae L. (Lepidoptera, Noctuidae). Doctoral thesis. Trondheim, NTNU: 15-32.

Vacchi A. 2006. Riconoscere e combattere le nottue defogliatrici. L'Inf. Agrar., 21: 67-71.

Vacchi A., Cioni F. 2006. Lepidotteri dannosi alla barbabietola da zucchero. Inf. Fitopatol. 10: 9-15.

Wiech K., Kalmuk J. 2004. The Influence of Undersowing White Cabbage with White Clover on the Occurrence of Some Lepidoptera Pests. Acta Fytotech. Zootech., 7: 351-355. 